\title{
Entrevista com o Prof. Dr. Sebastian Scheerer
}

Tamires Maria Alves e Gabriela Laura Gusis

\author{
Sebastian Scheerer \\ É ex-diretor do Instituto de Criminologia da Universidade de \\ Hamburgo e Professor do Departamento de Criminologia na \\ mesma universidade (Hamburgo, Alemanha) \\ E-mail: sebastian.scheerer@wiso.uni-hamburg.de \\ ORCID: https://orcid.org/0000-0002-8622-0463
}

\section{Entrevistadoras (Tamires Alves e Gabriela Gusis):}

Olá Sebastian, como vai? Eu vou Ihe fazer algumas perguntas mais sobre o seminário que você vem realizando na Universidade de São Paulo e os tópicos que têm trabalhado neste: homicídios, prisões e drogas. Primeiramente obrigada por ter aceitado realizar esta entrevista. Como estou realizando uma tese sobre Abolicionismo Penal é um privilégio tê-lo como entrevistado. Sebastian, você como Nils Christie, Thomas Mathiesen e Löuk Hulsman é considerado um dos pais do Abolicionismo Penal.

Nossa Revista é sobre Estudos Políticos então se você puder clarificar um pouco para os leitores do que se trata o Abolicionismo Penal seria muito importante para nós porque quando as pessoas escutam a expressão "abolicionismo penal" elas costumam ficar apavorados. As pessoas acreditam que é impossível pensar uma sociedade sem esta instituição prisional, então me parece necessário falar sobre o que de fato é o Abolicionismo Penal.

\section{Sebastian Scheerer:}

Sim, eu consigo entender essa reação. Quando nós começamos a falar sobre a abolição das prisões percebemos que era contraprodutivo se referir desta maneira. As pessoas pensam "nossa, esse homem é maluco" porque quando eles pensam que não existirão mais prisões então eles se questionam sobre os assassinos, os estupradores estarão todos nas ruas e eles farão o que eles quiserem e ninguém mais estará a salvo. Então não parece de fato muito produtivo falar que buscamos a abolição das prisões. É um problema didático na verdade. Porque a ideia inicial é que a sociedade resolve seus problemas sem as prisões, ou seja, sem estas nós teríamos mais segurança e não menos. E assim poderíamos ter mais segurança de uma maneira melhor e mais segura para lidar com os crimes e a delinquência. Mas essa não parece uma concepção muito fácil de se pensar. Isso porque comumente as pessoas costumam equalizar prisões com segurança. $\mathrm{E}$ a coisa mais importante seria então abrir a mente das pessoas para melhores maneiras de promover segurança do que as prisões. Mas isso nos traz tantos aspectos distintos que você me complica para esta entrevista.

Quando pensamos em exceções, como pessoas que são muito perigosas para a vida comum, como seriais killers. Então em praticamente todos os casos a respeito de seriais killers nós precisamos pensar em confinamento. Isso significa que precisamos colocá-los em prisões e não teremos como mudar esta questão para as pessoas muito 
perigosas. Agora eu sei que isso pode parecer uma contradição para a abolição das prisões. Mas eu tenho que ser a favor do confinamento dos considerados como indivíduos perigosos. Mas eu não sou a favor do confinamento como uma punição. Porque o confinamento precisa ser um mecanismo de segurança apenas para manter a sociedade segura destas pessoas.

Quando eu digo "a prisões precisam ser abolidas" o que isso significa é que a possibilidade de enviar uma pessoa para a prisão como uma punição pelo cometimento de um crime deve ser abolida. Como o Brasil já aboliu a possibilidade da pena de morte, a execução como punição. Os juízes no Brasil já não têm mais a possibilidade legal de dizer "eu te puno, eu irei te sentenciar a pena de morte", porque a sentença de morte já não existe mais no seu Código Penal. Em alguns outros países ela existe. Agora nós podemos imaginar um país que diga: "A pena de morte não existe no nosso Código Criminal e as sentenças de prisão também já não existem mais no nosso Código Criminal também. Mas existem outras punições, como: trabalho social, prisão domiciliar (embora ainda se chame prisão não é uma prisão efetiva. Você só necessita ficar em casa. Como acontece com alguns famosos envolvidos na Operação Lava a Jato. Eles têm casas ótimas, com muitos livros, com uma maravilhosa infraestrutura e eles apenas ficam em casa).

Então o que nós realmente temos são umas poucas pessoas em instituições que você pode chamar de prisões ou não, mas que não são utilizadas exatamente para punir estas pessoas, mas sim para garantir a segurança da sociedade, e é sobre isso que nós devemos pensar. Eu não vou chamá-las de prisões porque elas não estão aí para punir estas pessoas. Elas são como instituições psiquiátricas, nós não chamamos instituições psiquiátricas de prisões porque elas não foram criadas para punir as pessoas, mas sim para manter estas pessoas seguras e também manter a sociedade segura. $E$ isso é uma questão muito complicada porque ela tem uma alta carga política. E todos os grupos políticos interessados vão dizer: "Olha esta pessoa é perigosa então ela precisa ficar nesta instituição".

Olha, eu vou dizer que $95 \%$ ou mais do que isso das pessoas que estão nas prisões hoje eles não deveriam ter que continuar em confinamento por razões de segurança. Então nós não deveríamos ter mais de 600.000 ou 700.000 pessoas confinadas no Brasil, mas talvez 30.000 pessoas em instituições que não se pareceriam com prisões, e não seriam instituições que promulguem a punição. Estes lugares se pareceriam com apartamentos ou pequenas casas, bangalôs. E as pessoas ficariam nestes lugares porque a sociedade diria "Você precisa sacrificar a sua liberdade porque nós não sabemos o que fazer com a sua periculosidade". E isso já seria algo bastante complicado de se fazer, mas nós não prenderíamos centenas de milhares de pessoas. Talvez algumas centenas ou até mesmo, infelizmente, alguns milhares. Eu duvido que chegariam a esse número, quiçá a 10.000 pessoas, mas eu não sei. Porque tudo dependeria da definição de periculosidade. Nós só não permitiremos mais que a punição de pessoas seja realizada pela privação de liberdade destas, como, por exemplo, nós temos alguns crimes não violentos que se nós quisermos continuar punindo as pessoas nós deveríamos fazê-lo com sentenças alternativas.

Eu particularmente não costumo pensar que nós devemos punir as pessoas que cometem crimes violentos. Nós só devemos - e agora isso se torna bastante abstrato

- Nós só devemos restaurar a validade da norma que foi quebrada. Nós devemos fazer isso publicamente e efetivamente nós devemos chamar o sujeito para as suas responsabilidades. Este deve ser responsabilizado e nós devemos tentar restaurar o dano que foi causado a vítima, aos arredores da vítima, a comunidade. E aqui se torna 
complicado porque é necessária a participação da comunidade, mas isto será muito mais civilizado e terão maiores aspectos de restauração do que apenas a punição.

A punição é uma maneira autoritária de lidar com o comportamento problemático. Isso vem do tempo em que as regras advinham do Estado Absolutista. As leis do Estado Absolutista deveriam mostrar quem estava no poder e que o rei poderia esmagar qualquer pessoa que estivesse no seu caminho. Então este não era um jeito democrático de lidar com o comportamento contraventor ou mesmo com o comportamento perigoso.

Então esta tendência atual de justiça restaurativa tem muito da minha simpatia. Eu sei que as pessoas podem entender coisas distintas desta expressão "justiça restaurativa" mas o que eu entendo disso é que o sistema de justiça criminal nos questiona já que a lei foi quebrada quem quer que tenha feito isso deve receber uma determinada punição (dor) pra ser infligida a esta pessoa. Então a conta é de quantos anos eu envio esta pessoa para a prisão? E é só isso.

Então a Justiça Restaurativa tem uma visão completamente distinta de approach. A primeira pergunta é: que dano foi causado? Tanto para a vítima, quanto para as outras pessoas que sofreram danos. Porque muitas vezes se tem muitas vítimas, porque muitas pessoas são afetadas por um único ato. Então é muito importante enxergar quem foi e o que foi afetado e de que maneira, material, emocional, social. E só depois que nós encontremos o que foi que aconteceu e que tipo de prejuízo foi causado, então aí nós poderemos pensar o que nós podemos fazer e o que deve ser feito para tornar este prejuízo restaurado. Para resetar esta situação da melhor maneira que possa existir. Ou até mesmo poderemos pensar em tornar a situação melhor do que era antes. Porque a situação de antes muitas vezes tem alguma ligação com o que sucedeu a posteriori dela, então talvez essa situação anterior possa ser perfeitamente melhorada para que crimes como o que a sucederam não aconteçam novamente depois desta situação. Isso é o que Ruth Morris chama de Justiça de Transformação, nós não devemos apenas tentar restaurar, algumas vezes pode nem ser bom restaurar uma coisa que não era boa e que era injusta. Então às vezes não devem restaurar, mas transformar a situação anterior e modificá-la.

E apenas a partir daí uma terceira pergunta aparece que é: bom, alguém causou este sofrimento, quem é essa pessoa? E por que esta pessoa fez isso? E como fez isso? Vamos ouvir essa pessoa que parece ter responsabilidade sobre o ato. Mas não se deve fazê-lo de maneira que subjuguem e subordinem esta pessoa de maneira ofensiva. É preciso tentar que esta pessoa se sinta sem medos, podendo ter pessoas que ela estima ao seu lado, para que ela possa falar de maneira equitativa com os demais, e não como alguém que é inferior aos outros. Assim, ela poderá falar livremente e nós poderemos melhor entender quais foram as suas motivações naquela situação. E dessa maneira chegará o dia em que olharemos para os fatos narrados e pensaremos "bom, de que maneira essa pessoa pode restaurar ou transformar a situação anterior?" Essa pessoa não será deixada sozinha para fazê-lo, até porque nenhuma pessoa sozinha pode desfazer o sofrimento que fez o outro passar. É muito mais fácil criar sofrimento do que desfazê-lo. Então essa transformação da situação vai demandar muito mais gente e mais esforços.

Então você que o "criminoso" não é a pessoa central e infligir sofrimento a ele não é sequer a questão. Por outro lado, é muito importante olhar que tipo de atitude que este dito "criminoso" pode ter com a vítima, com as demais pessoas da sociedade. Esse processo inteiro pode ser um processo de conscientização sobre o sofrimento e o que este sofrimento fez e que responsabilidades ele tem sobre isso. Então esta pessoa 
tem que ser responsável, mas também adicionada e integrada, como Jonh Braithwaite dizia, você pode reintegrá-lo através da vergonha (reintegrated shaming). Isso não é sempre a melhor coisa a ser feita, mas pra se ter uma ideia reintegração através da vergonha pode fazer a pessoa pensar: "eu fiz um coisa ruim e eu percebo isso, eu tenho algumas razões boas e outras ruins por ter feito isto. Acredito que eu não quero fazer uma coisa dessas outra vez, e eu estou agradecido das pessoas me ajudarem, me auxiliarem a construir suporte emocional para enfrentar este momento". E é surpreendente como pesquisador o número de casos em que há ganhos emocionais estabelecidos no processo de conversar sobre o que ocorreu, que tipo de sofrimento foi causado. E isto é completamente diferente do que ocorre na justiça comum.

$\mathrm{Na}$ justiça comum tudo o que acontece é realizado de cima para baixo. A fala vem de cima, a sentença é feita de cima, a pessoa que cometeu o incidente é desvalorizada e colocada para fora da sociedade dentro da prisão, e na prisão ele geralmente se torna alguém muito pior do que era antes. $\mathrm{E}$ quanto mais tempo ele ficar aprisionado pior ele ficará. E quando esta pessoa sair da prisão ela sairá odiando a prisão, odiando os guardar da penitenciária, odiando a sociedade, odiando a polícia, odiando todo o mundo, inclusive a ele mesmo. $\mathrm{E}$ a estimativa é de que faça algo terrível novamente. $\mathrm{E}$ nós sabemos disso, os criminólogos sabem disso, então esta é a coisa mais estúpida a se fazer com a pessoa para apenas excluí-la, regrei-la, desvalorizá-la, despossuí-la (porque ela costuma sair da prisão com muitas dívidas) e ninguém se importa com isso. Ninguém quer ter relações com esta pessoa depois que ela sair da prisão exceto outros criminosos. Então é uma ideia estúpida colocar em prática este sistema penal que nós temos.

E nós acreditamos que vivemos numa sociedade Iluminada, nós vivemos numa sociedade medieval! Não é diferente dessa era medieval! Em muitos países criminalizam pessoas porque são gays, isso é completamente medieval. Em muitos países pessoas vão para as prisões porque traficam drogas. Quem trafica drogas não faz nada exatamente ruim. $O$ consumo de drogas pode ter consequências negativas, mas não tem nada a ver com a lei penal, é semelhante a questão do álcool. Se você colocar todos que produzem e vendem álcool nas prisões somente porque algumas pessoas matam outras depois de consumir álcool, isso é completamente insano. Isso não tem nada a ver com a dogmática legal e proteção legal de bens ou de pessoas. Isso é absurdo, é medieval e suas consequências são catastróficas porque destrói grande parte da sociedade e destrói a polícia por corrupção, destrói o judiciário porque eles não sabem mais o que estão fazendo e os força a serem hipócritas. E cria estruturas na sociedade onde a solidão é normal; onde a corrupção é normal; e isso vai diretamente para a identidade da sociedade.

Então nós estamos vivendo um sistema de justiça criminal que não está fazendo progressos, mas está caminhando para atrás. Todas estas legislações dos últimos anos são estúpidas e insensíveis. $E$ isso também nos mostra como a sociedade está desmoronando, com pessoas brancas não se importando com pessoas negras, ricos não se importando com pobres. $E$ é assim que a sociedade perde a sua orientação. $E$ isso não é apenas ruim para pessoas negras ou para pessoas pobres, é ruim para toda a sociedade. Então a justiça criminal precisa repensar toda a sua atuação e isso é a coisa mais importante que podemos fazer.

\section{Entrevistadoras:}

Muito obrigada por esta resposta tão esclarecedora para a nossa pergunta. Foi muito bom poder ouvir e entender que o abolicionismo não é sobre "por mais assassinos nas ruas" e sim sobre reflexões sinceras que devemos fazer a respeito das pessoas 
marginalizadas, principalmente. $E$ até para pensarmos sobre as pessoas que cometem os delitos, mesmo aos que envolvem situações de violência, mesmo se você cometeu um assassinato, é preciso que a sociedade olhe para você e pense se há tratamento para realizar e não apenas que a medida tomada seja jogá-lo numa instituição que tornará você pior.

\section{Sebastian Scheerer:}

Sim, é exatamente isso. E isso converge para uma extensão do que realizam os evangélicos. Porque por algum lado eles pensam parecido conosco, mas por outro lado eles não defendem o que defendemos porque pensam muito distinto em relação as drogas, por exemplo. Mas em termos de cuidar das pessoas, em tomá-los de verdade como pessoas que não são definidas completamente pelas suas ações, isso é algo que os evangélicos têm e que é muito bom. Você conhece as APACs? Assim eles acreditam dentro das unidades que gerenciam. Então há algumas coisas boas que podem ser conversadas com eles de maneira franca..., mas é difícil.

\section{Entrevistadoras:}

Sim, e no Brasil quando você começa a falar e explicar do que se trata o Abolicionismo Penal muitas pessoas dizem "Ok, mas isso é religião"...

\section{Sebastian Scheerer:}

Risos. Sim, sim! Mas há alguns pequenos aspectos em que realmente parecem se encontrar.

\section{Entrevistadoras:}

Sim, porque quando se fala em perdoar o outro, em olhar para além da ação que cometeu, isso parece um pouco um viés religioso, risos.

Bom, neste último livro que você escreveu "Manifesto para Abolir as Prisões", você e o Ricardo Genelhú discorrem a respeito de aspectos que já foram trabalhados por outros autores como John Braithwaite e até mesmo o que discorre a ICOPA - International Conference of Penal Abolitionism que Louk Hulsman fundou. No livro vocês falam sobre outras possibilidades de se trabalhar com uma sociedade sem prisões. Você acredita que estas alternativas possíveis como os hospitais psiquiátricos que permanecem com o paciente em análise, vendo quais seus avanços e se progrediu e poderia mudar para um regime de semiliberdade etc., poderiam ocorrer com pessoas que cometeram espécies de "delitos" considerados violentos?

\section{Sebastian Scheerer:}

Bom, primeiramente eu acredito que nem todo assassino é perigoso. $O$ fato isolado de que alguém matou outra pessoa não significa que esta pessoa vai ter que ficar confinada. É claro que pode ser que sim, ela tenha que ficar confinada.

No momento em que alguém mata outra pessoa é preciso que esta seja colocada em confinamento, como uma prisão provisória, porque nós não sabemos para onde esta pessoa vai e nós não podemos permitir que ela desapareça. Até porque quem saberia se essa pessoa não irá fugir para outro lugar e neste novo local ela poderia matar outra pessoa. Para isso é preciso que haja a prisão preventiva. Mas esta prisão preventiva é para garantir que o processo ocorra, logo o objetivo não é a punição. Portanto a prisão preventiva deve ser realizada num ambiente muito bom porque você não foi julgado, você não é culpado e você não está ali para ser punido apenas para que a justiça garanta que você estará ali enquanto analisam a sua situação. Então é um confinamento profissional que não precisa ser realizado na prisão, não é punitivo, 
mas precisa ser seguro.

O que o abolicionismo pretende fazer acabar é com a prisão como punição, a prisão como sofrimento. Se nós tivermos que punir as pessoas, nós podemos fazê-lo de maneira distinta a morte e também distinta da prisão. Nós podemos ter criatividade para lidar com nossos problemas. Você sabe, nós vivemos num tempo em que temos tantas possibilidades de vigilância que nós não precisamos colocar pessoas em celas pra ter certeza de que temos controle sobre elas. E esse é um argumento sociológico para o abolicionismo. Hoje em dia nós podemos analisar a situação social, nós podemos encontrar como nós podemos ajudar a pessoa ao mesmo tempo que a controlamos e fazemos esta pessoa responsável pelo que cometeu, ou sem necessitar punir a pessoa com a prisão. E esse é um pensamento do século XIX o do aprisionamento embora a gente viva no século XXI e ele continue em voga...

Algumas coisas de lá pra cá aconteceram, como estes dispositivos eletrônicos que existem hoje em dia, as tornozeleiras, ou os milhares de tipos de câmeras diferentes e você também tem pessoas, você tem trabalhadores que são assistentes sociais. Se usarmos o dinheiro destinado para as prisões para os assistentes sociais que irão realmente se importar e cuidar das pessoas para controlá-las e para manter as pessoas que eles chamam como "criminosos" em vigilância, então assim com estas mudanças, poderemos fazer muitas coisas.

Até mesmo nos Estados Unidos eles tem programas que são bastante interessantes sobre isso. Um deles é chamado reinvestimento da justiça criminal (criminal justice reinvestment). Neste, o governo federal envia dinheiro para os estados e condados que investem em sentenças não prisionais para pessoas que normalmente iriam as prisões. E eles recompensam os que são capazes de criar estas alternativas. E como eles fazem isso? Eles enviam o dinheiro que seria investido nas prisões e não está sendo gasto - porque se você enviaria 1000 pessoas para a prisão e não o está fazendo, você está economizando esse dinheiro que seria destinado a prisão destes 1000 , então, isso é bastante dinheiro. E esse dinheiro é enviado ao estado e a comunidade para investir nos quartos e na sala de estar destes ditos "criminosos". Assim, as salas de estar destes é limpa, a infraestrutura é melhorada etc. Isso se chama criminal justice reinvestment. Em alguns Estados como a Virgínia, eles estão fazendo isso e está parecendo uma alternativa interessante.

E nós precisamos ser muito mais inventivos! Quando você fala sobre um, eu não gostaria de citar justamente este caso clichê do taxista, mas é a realidade, ontem eu estava falando com um taxista e quando eu perguntei o que deveríamos fazer contra os criminosos ele rapidamente me respondeu: "colocá-los na prisão por mais tempo! Deveriam colocar mais pessoas na prisão, por mais tempo!" algumas vezes dizem: "podem morrer na cadeia! Matem estes criminosos!". É claro que nós podemos fazer isso, mas aí teremos uma sociedade distinta, uma ainda mais bárbara. E se você gostar de uma sociedade bárbara, tudo bem. Mas muitas pessoas querem viver em uma sociedade mais civilizada.

E o processo de civilização tem muitas coisas a fazer, como: a maneira que se tratam os pobres; como se tratam as minorias; e até mesmo como se tratam os "criminosos". Então se nós queremos uma sociedade melhor, mais feliz do que hoje em dia e também menos agressiva, nós devemos inventar métodos que sejam mais fabulosos e inspiradores do que os que matam as pessoas e as deixam presas eternamente dentro das prisões, onde elas serão mortas. É uma questão de prioridades.

A minha prioridade é que eu quero morar numa sociedade mais feliz onde as pessoas 
são decentes, civilizadas, na qual nós não nos matamos, onde os mais poderosos não matam os menos poderosos e vice-versa. E esse tipo de sociedade parece uma coisa bacana de se ter. $E$ para termos isso é preciso que tentemos começar a ter boas ideias do que pode ser muito bom para todos. $\mathrm{E}$ o que for ótimo para todos com certeza vai nos levar para longe deste tipo de pensamento horrível que chamamos de prisões. É bastante lógico!

Mas há tanta frustração na sociedade e quanto mais desiguais as sociedades, estas que estiveram períodos grandes de escravidão, como vocês no Brasil, elas são piores d que as outras. É terrível de dizer isso, mas é provavelmente verdade. Eles têm esta questão histórica muito forte. $\mathrm{E}$ eu entendo disso porque a Alemanha é uma sociedade que foi nazista e nós temos que tentar lidar com isso também e é muito difícil de fazêlo. Mas nós precisamos tentar lidar com isto o tempo todo!

\section{Entrevistadoras:}

Sim, claro. E eu fico pensando que deve ser muito difícil pra você falar sobre o abolicionismo e discutir estas ideias porque quando você começou a escrever sobre este tema a sociedade estava muito diferente, decaindo o número de prisões, parecia um cenário próspero pra falar sobre isso. $\mathrm{E}$ agora nos encontramos no extremo oposto... Caminhando para cada vez mais prisões.

\section{Sebastian Scheerer:}

Sim! Risos... Sim! Tudo estava caminhando por outra direção. E você está certa, estamos prendendo cada vez mais pessoas. Todavia, acredito que isto está chegando num ponto tão absurdo que cada vez mais pessoas se questionam sobre esta insanidade que está ocorrendo. Algumas pessoas estão começando a se perguntar: "olha será que não devemos voltar atrás?". É claro que há pessoas que também dizem: "Precisamos criar mais prisões! Só isso nos trará mais progresso". Isso é terrível e nunca funcionou...

Mas, por outro lado, há pessoas que estão pensando que é preciso se delimitar números para que a situação volte minimamente para o normal. Mas mesmo esta delimitação foi a situação que nos trouxe já até este hiperencarceramento da atualidade. Então, nós não devemos restaurar o cenário para quando tínhamos apenas 300 mil presos ou 400 mil presos. Nós precisamos transformar a situação! É outra razão pela qual a justiça transformativa faz sentido. Quando algo sai tão do controle como a justiça criminal e o sistema prisional, você não pode apenas dizer: "É verdade, isso saiu do controle. Vamos tentar controlar isto novamente". Isso é um sinal de que o tempo da prisão expirou! Assim como tempo das penas de morte expirou, e o tempo dos gladiadores expirou, o tempo de Tróia expirou... Então, agora expirou o tempo das prisões e nós precisamos entender que estamos num novo momento e que nós temos todas as possibilidades para inventar novas possibilidades.

E será triste se nós abolicionistas nos convertermos em apenas meia dúzia de pessoas falando sobre a necessidade do fim das prisões. Talvez possamos olhar para este cenário de crise da prisão como uma oportunidade para a sociedade compreender que apenas colocar as pessoas nas prisões e em celas minúsculas e superlotadas já passou, não funciona mais e nem nunca funcionou, e hoje nós temos milhares de novas possibilidades para se lidar com os conflitos.

\section{Entrevistadoras:}

Sebastian é incrível que você pense e milite desta maneira. Parece uma visão otimista da crise que estamos enfrentando hoje. 
Nós da América Latina e do Brasil estamos cada vez com os planos de crescer ainda mais novos complexos penitenciários. Como você deve saber, hoje em dia temos 726 mil presos no Brasil. A guerra contra as drogas é responsável por manter presos a maior parte destes apenados. Nós sabemos que eles são os bodes expiatórios, ou seja, jovens, negros, pobres, com baixa escolaridade e sem empregos ou moradia fixos. Os pesquisadores que discutem que a questão de drogas deveria ser tratada como uma política pública de saúde e não através da justiça criminal. Entretanto, muitas vezes a postura dos cidadãos comuns é acreditar que os que defendem que as drogas poderiam ser utilizadas ou que o consumo e o comércio destas não deveriam levar as pessoas às prisões, são acusados de apologistas ou usuários. Isso porque acreditam que quem defende o não encarceramento de traficantes ou usuários não pode apenas crer nisto por ser contra as prisões.

Isso me preocupa porque vai além dos problemas que temos com os mais conservadores das mais variadas classes sociais. Falo isso porque mães e pais que perderam os filhos por conta do vício com as drogas ou porque trabalhavam para o tráfico, ou mesmo mães que perderam seus filhos apenas para a violência gerada e não porque estivessem envolvidos com drogas, clamam pelo fim do uso e comércio das drogas. Estas pessoas muitas vezes dizem: "Nós odiamos as drogas! Queremos o fim das drogas!"; "Nós vivemos em comunidades em que a polícia invade e mata inocentes por conta das drogas"; "Meu filho era dependente de drogas e morreu por consumo de drogas!". E esta me parece uma questão bastante sensível. A guerra as drogas mata um número muito grande de pessoas inocentes e parece difícil explicar para os que perderam seus afetos que as drogas podem ser usadas e comercializadas legalmente e de maneira recreativa

\section{Sebastian Scheerer:}

Sim, isso é uma questão muito complicada porque as drogas são como o álcool. Elas são substancias arriscadas para a recreação. Isso também é verdadeiro para cigarros, para cachaça, para vinho, cerveja... É claro que de maneiras distintas, mas é tudo verdade de que são substancias problemáticas as drogas, tanto as legais quanto as ilegais. $\mathrm{E}$ isso torna a questão muito difícil, até porque muitas vezes as drogas matam sim as pessoas. O uso das drogas pode matar as pessoas, o álcool, o tabaco, as drogas ilícitas, todos matam muitas pessoas. Então, isso é verdade, todos sabemos disso. E eu não me oponho a famílias que digam: "Na nossa família ninguém vai usar drogas, nós não toleraremos este tipo de comportamento". E entendo pais que digam para os seus filhos: "Não saiam com crianças que os seus pais consumam drogas". Isso é completamente viável e pode ser bom para estas pessoas.

E ao mesmo tempo é muito difícil dizer: "A legislação sobre as drogas é ruim. E deveria ser desfeita e as drogas deveriam ser legalizadas". Pode parecer uma contradição, mas na realidade não é porque uma legislação de drogas ruim cria muito mais perigos para as pessoas que gostam de utilizar as drogas recreativamente. Quando você tem uma lei sobre drogas ruim, então terá um ataque as drogas onde você poderá tomar tiros e ser morto, porque você está perto de alguém com drogas. Os seus filhos(as) podem experimentar drogas e eles podem entrar numa fase em que consumam drogas mesmo que você seja contra o uso destas. Eles podem ser parados pela polícia e podem ir a prisão e dentro desta podem ser mortos, isso acontece... E estas pessoas todas poderiam estar vivas se as drogas não fossem proibidas. Poderia ser encarado que utilizar as drogas quando adolescente é uma fase, como é o caso do vinho e da cachaça, são fases para todos adolescentes. Apenas há os adolescentes que consomem drogas legais e eles tem maiores chances de sobreviver que os que 
consomem drogas ilegais. Podemos encarar que eles vivem esta fase e depois dela vão superá-la e se tornarão cidadãos comuns. Assim eles não passarão riscos de ir para instituições de menores, ou mesmo pra cadeias e depois de serem presos podendo até mesmo serem mortos nestas. Estas pessoas podem ser mortas na cadeia, ou por policiais etc.

Então por que não tratamos as drogas ilegais como tratamos as legais? Nós podemos ser contra elas, podemos falar para nossos filhos(as) não as consumirem, mas se eles experimentarem, eles não deveriam ir para as prisões. Meus filhos não foram para as prisões por beberem álcool, mesmo que eu tenha lhes dito para não fazê-lo. E eu fico feliz que não tenham ido presos! Meu pai não foi a prisão porque fuma a tabaco, e fico feliz por ele também. Ele poderia ter sido morto dentro de uma penitenciária se o cigarro fosse ilegal e uma vez lá dentro, poderia ter sido morto. E se ele tivesse morrido eu sequer existiria, e isso seria muito triste para mim, risos.

Então é tão lógico que a criminalização das drogas é um risco adicional para o risco das drogas. E hoje muito mais pessoas morrem por conta deste risco adicional da proibição das drogas e da guerra as drogas, do que morrem pelo consumo dos entorpecentes. Provavelmente no Brasil, até esse mês de junho de 2018, ninguém morreu este ano por ter fumado maconha. Mas muitas pessoas que lida com a maconha, que trabalha com a maconha, provavelmente muitas delas foram mortas por causa da guerra as drogas. Então, muito mais pessoas que tem alguma ligação com a maconha morrem por causa da proibição das drogas do que pelo consumo delas. Como podemos fazer uma lei que faz mais mal para a sociedade do que o objeto que a lei é contra? Isso não é racional! E o mesmo passa com as outras drogas ilícitas.

Em Portugal eles têm uma Lei de Drogas de 2001 que descriminaliza todas as drogas, ao menos para o consumo. Se você é traficante eles continuarão e enviando para a prisão, mas se for provado que você é consumidor, não importa que tipo de droga você tenha, eles nunca vão te mandar para a prisão. Mesmo que eles te encontrem 20 vezes com drogas, mesmo que seja ópio, você não irá para a prisão por consumo de drogas. Eles podem te recomendar que você busque tratamento, psicólogos, grupos de narcóticos, mas não lhe enviarão para a prisão. E parece algo simples que é fantástico porque funciona. As pessoas estão mais felizes em Portugal porque pensam que as coisas estão mais fáceis do que nos territórios em que os países proíbem as drogas. Porque nestes lugares a droga é uma tensão e um perigo. Reiterando que este perigo não vem da droga, mas vem da proibição destas.

Então, eu apoio todos que dizem que não gostam de drogas, que não querem proválas e nem desejam que seus familiares tomem contato com estas. Mas eu quero que as drogas ilegais sejam tratadas legalmente como tratamos o tabaco e o álcool. E eu sou contrário as proibições de álcool que nunca funcionou, não irá funcionar e cria uma série de problemas extras. Eu também sou contra a proibição dos cigarros. Mas eu sou a favor de todas as restrições que dizem para as pessoas não fumarem nos shoppings, nos restaurantes, no trabalho. . . Isso é muito bom, mas nós não devemos proibir os cigarros, mesmo que eles matem as pessoas. Até porque se proibirmos os cigarros nós vamos criar o mesmo problema que temos com as drogas ilegais, onde criamos ainda mais pessoas mortas do que se elas apenas fumassem. E hoje em dia nós temos ótimos artigos científicos, escritos por pesquisadores sérios, que nos alertam que se a proibição do cigarro vigorar ela trará os mesmos problemas que enfrentamos com a guerra as drogas, só que potencializados.

Então eu sou um fã do modo como o Uruguai tratou a questão das drogas. No Uruguai a Lei das Drogas mais progressista está prevista apenas para a cannabis, mas lá eles 
de fato legalizaram a cannabis, ou seja, não há perigo de um policial fichar um usuário ou prendê-lo, não há perigo de exclusão social por uso, e essa é a maneira como deveríamos lidar com a questão de drogas. E é como poderíamos lidar com todas as drogas, não apenas com a maconha.

\section{Entrevistadoras:}

Bom, esta pergunta é mais referente a sua última aula na USP. Durante sua palestra você elencou 8 tipos de assassinatos: aborto, genocídio, suicídio, guerras, punições, legítima defesa, eutanásia e homicídio. Quando você falava disso eu pensava que vocês na Europa enfrentam hoje o grande problema dos refugiados. É possível perceber que não é uma morte direta porque não os assassinam, mas deixam os mesmos morrerem. $E$ aqui no Brasil nós temos um grande problema também que são as pessoas muito pobres, abaixo da linha da miséria que morrem por fome, não têm acesso a saúde, educação etc. Então fiquei me perguntando se esses crimes de Estado não podem ser considerados como assassinatos? Porque fico pensando que não são mortes diretas entre pessoas, mas é o descaso dos Estados que acaba por assassinálas.

\section{Sebastian Scheerer:}

Essa é uma ótima pergunta. A diferença entre assassinato direto em que se promove a morte e o outro caso é deixar que o sujeito morra. Na lei eles normalmente distinguem isso entre matar ativamente uma pessoa ou deixar uma pessoa morrer. A ideia básica é de que quando você mata diretamente uma pessoa é entendido como homicídio, moralmente e legalmente repreensível. Agora quando você deixa uma pessoa morrer legalmente você não é culpado por um crime, porque você não fez nada. Então, deixar alguém morrer é moralmente difícil, mas legalmente está ok.

Existem claro, exceções, como quando você é o pai de uma criança que está para morrer, você não pode deixá-la morrer que isso será entendido como homicídio porque você não fez nada. É uma perversidade que não é permitida pela sua posição de alguém que tem que cuidar dessa criança, você tem esta obrigação de cuidar desta pessoa. E se você não toma conta dela, então a lei irá tratá-lo como responsável por tê-la deixado morrer e pode ser valorado como um ato ativo.

Na filosofia você tem um caso muito peculiar chamado $O$ caso do carrinho (The Trolley case). Neste caso você tem um trem que não tem nenhum condutor na locomotiva, e o trem está descendo para perto de 3 pessoas que estão nos trilhos. E estas pessoas não podem ouvi-lo porque estão trabalhando, e não sabem que o trem se encontra sem o maquinista, descendo reto, e vai de encontro a eles. E você está pero deste trilho e vê o que está acontecendo. E você vê que há uma interseção em que o trilho pode cair pra direita ou seguir reto. E você pode mudar a direção do trem puxando uma alavanca, o que faria com que o trem virasse para a direita. Você está perto dessa alavanca e é fácil de fazê-lo. Então, claramente você fará isso, é fácil de responder a esta questão. Mas então você vê que no trilho a direita tem uma pessoa no trilho do trem. Então o que você fará: Você mudará a direção do trem? E este é o The Trolley Case. Então o dilema é: você fará algo para salvar três pessoas, mas você optará por que a uma pessoa no trilho a direita morra. Não é que você exatamente matou esta pessoa, mas você terá puxado uma alavanca que ocasionou a morte dela. Mas a boa notícia se você escolher isso é que apenas matará uma pessoa em detrimento de três pessoas. Quando você não faz nada as três pessoas irão morrer, mas você não é o pai destas pessoas, você não tem nenhuma obrigação legal com elas para salvá-las. Você pode apenas deixar acontecer o que já estava acontecendo, que é o trem descer o 
trilho em direção a elas.

E é uma pergunta muito interessante pensar o que você faria, ou o que você deveria fazer. A maioria dos homens respondem que eles mudariam a direção do trem e salvariam três pessoas ao invés de uma única pessoa. Eu fiz este experimento com as pessoas e, em contrapartida, a maioria das mulheres dizem que não mudariam o curso do trem, porque o que o destino poderia sempre mudar de maneira imprevisível. As vezes o trem poderia descarrilhar antes de descer até as três pessoas, o que não é parte do problema, mas alguns tentam inventar mecanismos para lidar com esta escolha. E muitas delas dizem: "Bom, eu não sou a mãe destas pessoas, eu não tenho que escolher quem irá morrer. É trágico o que irá acontecer, mas eu não quero me sentir responsável pela morte de uma pessoa, porque quando eu mudo o rumo do trem eu decido quem irá morrer. Eu intervenho e me sinto culpada".

Então é uma pergunta muito complicada de se responder. E fica ainda mais complicada quando você não senta apenas perto desta alavanca que você pode mudar o rumo, mas sim, você está na ponte, antes da bifurcação do trilho, mas longe da alavanca. Na ponte você pode ver tudo que ocorrerá, mas você não tem a alavanca para mudar o rumo do trem. Todavia, atrás de você tem um homem muito gordo e seria muito fácil pra você apenas jogá-lo pra baixo e ele bloquearia o trem de ir pra qualquer um dos dois lugares.

Neste caso, a maioria das pessoas que diziam que mexeriam na alavanca não são capazes de dizer que jogariam o homem gordo no trilho. Mesmo que saia no mesmo, você estaria sacrificando uma pessoa no detrimento de outras. Mas o mais interessante disso tudo, e agora chegamos na pergunta do "deixar a pessoa morrer". De alguma maneira, a maioria das pessoas não iria jogar o homem gordo, porque existiriam instintos morais de que é um assassinato jogar uma pessoa da ponte para impedir que o trem desça e mate três pessoas. E as pessoas não querem cometer um assassinato, mesmo que este assassinato realize efeitos positivos. É algo moralmente distinto de cometer um assassinato para fazer algo bom ou deixar alguém morrer para fazer uma coisa boa.

Não fazer nada não é mau por si só, mas matar uma pessoa sim é muito ruim por si só. Então você pode deixar as pessoas morrerem no Mediterrâneo, isso é ruim, e é triste também. E você pode perguntar: "Nossa, como você foi capaz disso?". Mas o sujeito não é o pai dessas pessoas, você não está matando estas pessoas diretamente, você está deixando que elas morram de fome ou no Mediterrâneo. Mas é diferente de você afogar a pessoa pessoalmente no Mediterrâneo. E isso na filosofia ocidental você pode ver na religião, pode ver em Thomas Aquino, ele também pensou sobre isso, de outra forma é claro, mas elucubrava sobre isso. E o que Tomás de Aquino falava é que você nunca pode optar por cometer o ato ruim na sua própria vida por nenhuma razão. Mas, por outro lado, não tomar partido e permitir que as coisas ocorram, podemos falar a respeito disso.

E eu acredito que essa linha de raciocínio nos segue até hoje. Acho que é uma pergunta de responsabilidade política e eu tenho certeza que os políticos alemães não acreditam que é responsabilidade política deles. Eles inclusive proibiram que fossem exportados bons barcos para a Líbia, porque acreditam que quando melhores os barcos mais pessoas iriam vir como refugiadas. Então estas pessoas teriam que ter os barcos ruins, que são mais perigosos. Isso é terrível.

Então pra responder à sua pergunta, trata-se de uma pergunta de responsabilidade política sim. Mas eu não a colocaria na mesma lista das de mortes ativas, ou seja, de 
pessoas matando pessoas. Isso são pessoas deixando outras pessoas morrerem, e isso é um tópico distinto. Claro que é um item muito importante, muito emocional e complicado de maneira filosófica, mas neste momento eu te responderia que há uma grande diferença.

\section{Entrevistadoras:}

Por fim, gostaria de perguntar sobre o que você disse que está pesquisando na agora. Você hoje nos contou na USP que tem esta nova teoria sobre os dois ciclos cheios (two full cicles). Você poderia nos explicar isto um pouco mais detalhadamente?

\section{Sebastian Scheerer:}

Sim, claro. Nós costumamos acreditar que a história dos aprisionamentos é uma história de progressos. Você tinha as casas de correção que confinavam pessoas de maneira indiscriminada, onde as pessoas ficavam em quarentenas solitárias por muito tempo, antes das celas. Quando estas surgiram eram limpas, bacanas, onde as pessoas realmente procuravam reabilitar as outras pessoas, então elas tinham boas intenções e até mesmo gastavam muito dinheiro nestes estabelecimentos. Este seria um bom progresso. E depois teriam ainda mais progressos quando se começassem as terapias dentro das prisões, com prisões abertas etc. Então, a ideia dos penalistas era de que se vivíamos em uma época de progressos, então poderíamos demonstrá-los através da manutenção com maestria das prisões.

Eu acredito que a ideia de progresso já está de antemão errada. O que realmente acontece continua sendo a prisão de pessoas de maneiras indiscriminada com a atualização para confinamentos em solitárias, por exemplo. Hoje nós podemos ver que o dito progresso não é linear, mas sim circular. E hoje em dia estamos voltando para o confinamento em solitárias, depois de todas estas "aberturas" da prisão, estamos voltando para este cenário de confinamento solitário. E assim podemos perceber como muitos outros prisioneiros estão sendo encaminhados para as solitárias nos últimos dez anos do século XXI enquanto isto era uma prática comum no século XVIII, como nos mostra o trabalho de John Howard, escrito em 1777. John Howard fez um enorme trabalho empírico sobre as prisões em que relatava exatamente como essas práticas eram nocivas e isto voltou para o cenário atual. Tudo o que John Howard descreve nos seus manuscritos sobre falta de higiene, corrupção, deterioração, são cenários exatamente iguais aos que enxergamos hoje nas prisões.

Então, o progresso pode parecer como um progresso porque olhamos para a situação degradante em que se encontram as prisões hoje, mas ele não é um progresso do ponto de vista histórico. É um retrocesso que gira em círculos. E isso é um ótimo sinal de como todo este sistema deve acabar de uma vez!

\section{Entrevistadoras:}

Sim. Muito bem Sebastian, eu te agradeço muitíssimo pela sua entrevista. Foi muito esclarecedor conversar com você sobre o abolicionismo e sobre o cenário de hiperencarceramento que enfrentamos hoje. Muito obrigada!

\section{Sebastian Scheerer:}

Imagina! Eu fico feliz em poder contribuir com você e com a sua pesquisa. 
(Recebido para publicação em agosto de 2020)

(Reapresentado em setembro de 2020)

(Aprovado para publicação em setembro de 2020)

\section{Cite esta entrevista}

SCHEERER, Sebastian. Entrevista conduzida por Tamires Alves e Gabriela Gusis. Revista Estudos Políticos: a publicação semestral do Laboratório de Estudos Hum(e)anos (UFF).Rio de Janeiro, Vol.11 |N.1, pp. 28-40, outubro de 2020. 